\title{
Importance of Assessment in ELT
}

\author{
Irfan Tosuncuoglu \\ Correspondence: Irfan Tosuncuoglu, Karabük Üniversity, Turkey. \\ Received: July 17, $2018 \quad$ Accepted: August 5, $2018 \quad$ Online Published: August 15, 2018 \\ doi:10.11114/jets.v6i9.3443 URL: https://doi.org/10.11114/jets.v6i9.3443
}

\begin{abstract}
Assessment has an important role in education and it has a critical role in the teaching process. Through appropriate assessment, teachers can classify and grade their students, give feedback and structure their teaching accordingly. Recently, educators and scientists have been becoming more interested in the requirements of assessment procedures in the scope of foreign language teaching and the learning process, as forms of assessment have been changing. The assessment procedures relate to authenticity, practicality, reliability, validity and wash back, and are considered the basic principles of assessment in foreign language teaching and learning. The main value of these aforementioned principles is to distinguish the effects of assessment and review any classroom based issues between the teacher and the student. As the assessment process affects both teachers and students, significance and consideration should be given to assessment procedures in foreign language teaching.
\end{abstract}

Keywords: assessment, forms, evaluation, testing, feedback

\section{Introduction}

A learner centric technique supports the perception that students should be active members of a class, and this has been a new approach to foreign language courses. In this vein, assessment activities in the classroom are used by language teachers to check student acquisition levels. It can be said that assessment is a long-term procedure and involves information and data regarding the development of the students.

Assessment has a vital impact in the education process to inform and improve ongoing learning, and plays a significant role (Cowie \& Bell, 1999). According to Pierce, (2002; cited in Kırmızı \& Kömeç, 2016), assessment is a crucial part of any learning and teaching activity. It not only informs instructional decisions made on a day-to-day basis and helps diagnose student strengths and weaknesses related to classroom instruction, but also provides specific feedback to students in support of their learning. Assessment also provides immediate feedback for teachers to shape their teaching practices according to the learning styles of their students. To assess student achievement and determine grades, teachers should use different tests. Tests, examinations and evaluation models are important tools, utilized as a measure of the learning process.

\section{Assessment \& Evaluation: Significance}

Assessment and evaluation are the main parts of teaching and learning activities. They have very close definitions and they are very often used interchangeably. However, they do differ from each other to some extent. Assessment is a general item, which consists of methods and techniques used to gather information about student ability, knowledge understanding and motivation (Allan, 1999; Ekbatani \& Pierson, 2000; Lambert \& Lines, 2000). Evaluation is the activity of collecting necessary information to determine if a program answers its goals. It aims to discover which methods work and which do not (Kaufman, Guerra, Platt, 2006). As is obviously understood from these definitions, assessment is the method, and evaluation is the process or activity. It can be inferred from this that one can apply assessment methods in the evaluation process.

Assessment is, on the whole, accepted as one of the very crucial parts of teaching, by this means, educators can determine the level of skills or knowledge of their students (Taras, 2005). Wojtczak, (2002) argues that it helps teachers evaluate the strengths and weakness of their students and to motivate them. In addition, assessments also provide teachers with useful feedback about student learning acquisition (Taras, 2005; Stiggins, 1992). This procedure allows teachers the opportunity to evaluate learning, and then use that information to improve student knowledge.

Assessments of foreign language teaching and learning are performed for a variety of reasons. Firstly, it reveals how many students have achieved their learning objectives in a foreign language, who has any difficulties or problems with their learning, and which techniques are useful in teaching a foreign language. Secondly, the teacher may decide whether or not to continue the foreign language-teaching program. 


\section{Assessment Selection}

Assessment selection is defined as a preference among available alternatives to assess, and the possible realization of these preferences. It can be said that, according to the teacher and student preferences, assessment type can either reduce stress and anxiety or increase it.

There are not many studies which directly analyze student choices and assessment formats, and which students will perform better on preferred formats of assessment (Black \& William, 1998; K. H., Wang, T. H. Wang, W. L. Wang, \& Huang, 2006; Watering, Gijbels, Dochy, \& Rijt, 2008). Berry (2010) argues that exams, testing and evaluation systems can evoke negative memories for learners such as being anxious, fearing failure, and worrying about what others may think of their abilities. These negative perceptions may affect performance to great extent. To this end, it is necessary to implement alternative ways of assessment, if the applied assessment format is not at the desired level to improve teaching. All the same, some negative outcomes based on assessment, leave learners less motivated and more psychologically stressed. This situation may prevent learners being motivated to learn a language.

The provision of ongoing feedback to the student by means of assessment by the teacher can maximize acquisition in the learning process. To positively address learner anxiety, or concern about assessment, it is vital to use modern testing practices together with traditional ones. In traditional assessment procedures, the aim is to check the recent performance or activities of the student or learner through tools such as test questions, alternatives, cloze tests or fill in the blanks. These performance oriented testing activities may allow learners to be successful in the short term rather than in the long term. For these reasons, it is necessary to eradicate student anxiety or worry, and teachers should maintain motivation at the highest level. Essentially, the assessment preference can have a significant impact on foreign language teaching and learning processes. Scientists define assessment as the process of collecting data with the aim of identifying problems. Five primary types of decisions that can be made from assessments have been identified. These are decisions about referral, screening, classification, instructional planning and student progress evaluation. For each of these decisions, academic, behavioral or physical problems may be the targets of assessment (Shapiro, 1987). During the teaching of foreign languages, teachers generally evaluate language ability, which they collect by means of tests and exams. Also, they often prefer ready-made tests for use in their classes.

Comparing traditional forms of assessment of foreign language and using current forms of assessment in teaching practice, linguists offer the table below, which reflects the changing paradigm in education in general and in second language teaching in particular.

The table includes comparisons between some issues of the old paradigm and the new one.

Table 1. Old and new paradigm

\begin{tabular}{ll}
\hline Old teaching foreign language paradigm & New teaching foreign language paradigm \\
\hline Focus on language & Focus on communication \\
Isolated skills & Integrated skills \\
Teacher-centered & Learner-centered \\
Emphasis on output & Emphasis on procedure \\
Tests only test & Tests to teach \\
\hline
\end{tabular}

\section{Alternative Assessments}

Today, English language teachers are starting to realize that new alternative assessment strategies need to be developed to better monitor and serve their students in their learning progress. These new forms of assessment concentrate on measuring student knowledge to use language spontaneously in real life and are normally realized over a certain period of time. In addition to this, the more authentic variety of assessments, as projects, performance assignments, concept maps, self-assessment, peer-assessment, observation, portfolio, drama, diagnostic tree, journals, posters, instructors and student interviews (Anıl \& Acar, 2008; Büyüktokatlı \& Bayraktar, 2014) have become increasingly common in the classroom. The differences between traditional and authentic testing are as in the following.

Table 2. Traditional and Authentic testing

\begin{tabular}{ll}
\hline Traditional & Authentic \\
\hline Selecting a Response & Performing an assignment \\
Contrived & Real-life \\
Recall & Construction \\
Teacher-based & Student-based \\
Indirect & Direct \\
\hline
\end{tabular}

http://jfmueller.faculty.noctrl.edu/toolbox/whatisit.htm

According to Richards and Renandya, (2002) "alternative assessment has been described as an alternative to standardized testing and all of the problems found with such testing. There is no single definition of alternative assessment". Alternative 
assessment is different from traditional testing in that it actually asks students to show what they can do.

Students are evaluated on what they integrate and produce rather than on what they are able to recall and reproduce. Thus, alternative assessment is realized in classroom activities and reflects and suits the requirements for the syllabus. Moreover, the data collected is based on real life assignments, alternative assessment providing information on the strengths as well as the weaknesses of a student.

Thanks to alternative assessment, learning becomes more authentic because it helps students improve their decision-making and problem solving skills (Brualdi, 1996). Teachers are also able to gain insight about their course effectiveness and make alterations if necessary.

\section{The principles of Assessment}

Assessment includes information about student awareness, understanding, perception and attitude to learning. Assessment answers the needs of the student and is central to teacher planning, including testing. In this vein, Brown \& Abeywickrama (2010) and Sarıçoban (2011) argue that standardized tests have been most often associated with the terms of the following assessment principles: authenticity, reliability, validity, and the washback effect. Here they are explained in detail.

\subsection{Authenticity}

Basically, using the principle of authenticity in a test uses the test for performing an assignment in a real life situation. Thus, in a test, authenticity may be presented in the following ways;

a) includes as much natural language as possible

b) contains components which are contextualized

c) has meaningful, relevant, real life themes

d) provides some thematic organization to items, such as a story line or episode

e) offers assignments that replicate real world assignments (Brown, 2010).

\subsection{Reliability}

The stability and the consistency of performance reliable test has to be consistent and dependable, (Badjadi, 2013; Genesee \& Upshur, 1999). For instance, if a teacher gives the same test to the same student or matched students on two different occasions, the test has to show the same results. So the principle of reliability;

a) is consistent in its conditions

b) gives clear directions for evaluation

c) has uniform rubrics for evaluating

d) contains assignments that are unambiguous for the test-taker, (Brown \& Abeywickrama, 2010).

Richards and Renandya (2002) say that if a procedure is valid, it is reliable and it gives the same conclusions. The possible realization rate is extremely high, for example if a student's written story shares the same, or at least highly similar, characteristics of his/her subsequent writing.

\subsection{Validity}

"Validity of assessment is perceived when the assessment method is consistent with the material and curriculum being taught and if the results of the assessment are accurate" (Brown, 2002; Gür, 2013). Supporters of alternative assessment do not suggest that these criteria be skipped. Concerns with validity and reliability of assessment tools have been addressed in qualitative research through the use of the term honesty. In other words, it measures what it is supposed to measure and would the instrument give the same results if it is repeated.

If we show Reliability and Validity in a diagram

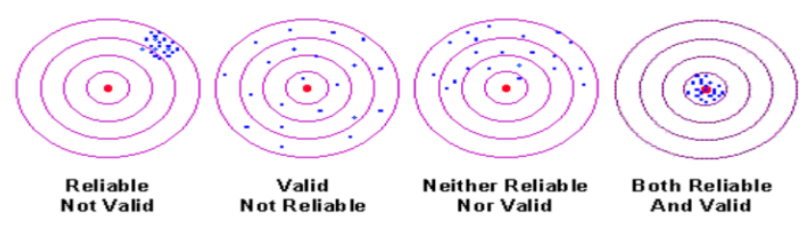

https://socialresearchmethods.net/kb/relandval.php 


\subsection{Washback Effect}

The fourth primary principle of foreign language testing is washback effect. According to Brown (2004), and Anderson, Rourke, Archer, \& Garrison (2001), this principle is defined as the effect of testing on teaching and learning a foreign language. Another point of view on the washback principle is that the washback effect may denote both the promotion and the self-consciousness of language learning.

This principle reflects how tests influence both teaching and learning. The following issues have to be put into consideration when using washback;

a) positively influences what and how teachers teach and how students learn

b) suggests students have a chance to prepare

d) gives students feedback data to evaluate language achievement

e) provides conditions for peak performance by the student (Brown \& Abeywickrama, 2010).

\section{Conclusion}

Testing concerning assessments can provide both teachers and students with information about the level of knowledge, skills, difficulties in foreign language learning and which activities and methods are the most useful. Testing is a means of evaluation of student activities and can be used for a clear criterion or scale. The word assessment means the consideration of a person and an evaluation of them, and has a wider rationale than testing (Akpinar \& Çakildere, 2013; Brown, 2004), which can be used with the items, to test, measure and evaluate. In the light of alternative assessments, teachers may identify what is important in their teaching process and select assessment strategies suitable for the characteristics of the learners.

Knowing and organizing principles of assessment, develops the planning of assessment of a foreign language. So the following issues have to be taken into consideration by the teacher, in the planning of teaching foreign languages with regard to assessment:

1. Instruction and assessment should reflect one another

2. All kinds of assessments are meaningful while using foreign language.

3. Assessment must have a primary place in teaching

4. Assessment principles have to be put into consideration for creating teaching materials by the teachers, for the students.

5. Negative factors that affect learners such as anxiety and worry, should be the focus of teacher attention.

To sum up, the significance of assessment in the process of language teaching has been known recently. Assessment is very important for the students to acquire a language. It plays a crucial role in the process of learning, and connects students to new knowledge using their current abilities.

\section{References}

Akpinar, K., \& Çakildere, B. (2013). Washback Effects of High-Stakes Language Tests of Turkey (KPDS and UDS) on Productive and Receptive Skills of Academic Personnel. Journal of Language and Linguistic Studies, 9(2), 81-94.

Allan, D. (1999). Testing and Assessment. English Teaching Professional, 11, 19-20.

Anderson, T., Rourke, L., Archer, W., \& Garrison, R. (2001). Assessing teaching presence in computer conferencing transcripts. Journal of the Asynchronous Learning Network, 5(2).

Anıl, D., \& Acar, M. (2008). Sınıf öğretmenlerinin ölçme değerlendirme sürecinde karşılaştıkları sorunlara ilişkin görüşleri. Yüzüncü Yll Üniversitesi Eğitim Fakültesi Dergisi, 5(11), 44- 66. DOI: 10.14527/ pegegog.2014.006

Badjadi, N. E. I. (2013). Conceptualizing Essay Tests' Reliability and Validity: From Research to Theory. Online Submission.

Berry, R. A. (2010). Preservice and Early Career Teachers' Attitudes toward Inclusion, Instructional Accommodations, and Fairness: Three Profiles .The Teacher Educator, 45(2), 75-95. https://doi.org/10.1080/08878731003623677

Black, P., \& William, D. (1998). Inside the Black Box: Raising standards through classroom assessment. Granada Learning.

Brown, G. T. L. (2002). Teachers ' Conceptions of Assessment. (Doctoral dissertation, University of Auckland).

Brown, H. D. (2004). Language Assessment Principles and Classroom Practices. New York: Pearson Education. Inc.

Brown, H. D., \& Abeywickrama, P. (2010). Language Assessment: Principles and Classroom Practices. White Plains, 
NY: Pearson Education, Inc.

Brualdi, A. C. (1996). Multiple Intelligences: Gardner's theory. ERIC, Clearing house on Assessment and Evaluation, Washington, DC. (ERIC Digest: ED 410 226)

Büyüktokatlı, N., \& Bayraktar, Ş. (2014). Fen eğitiminde alternatif ölçme değerlendirme uygulamaları. Pegem Ĕgitim ve Öğretim Dergisi, 4(1), 103-126. https://doi.org/10.14527/pegegog.2014.006

Cowie, B., \& Bell, B. (1999). A Model of Formative Assessment in Science Education. Assessment in Education: Principles, Policy \& Practice, 6(1), 101-116. https://doi.org/10.1080/09695949993026

Ekbatani, G., \& Pierson, H. (2000). Learner-Directed Assessment in ESL Mahwah. NJ: Lawrence Erlbaum Associates.

Genesee, F., \& Upshur, J. (1999). Classroom-Based Evaluation in Second Language Education. USA: Cambridge University Press.

Gür, O. (2013). Ölçme, Değerlendirme ve Kamu Personel Dil Sınavı (KPDS) - Bu Sınav Neyi Ölçüyor? Sakarya University Journal Education, 23-32.

Kaufman, R., Guerra, I., \& Platt, W. A. (2006). Practical Evaluation for Educators Finding What Works and What Doesn't California. Corwin Press. https://doi.org/10.4135/9781412990189

Kırmızı, Ö., \& Kömeç, F. (2016). An Investigation of Performance-Based Assessment at High Schools. Unniversitepark Bülten, 5(1-2), 53-65. https://doi.org/10.22521/unibulletin.2016.512.5

Lambert, D., \& Lines, D. (2000). Understanding Assessment: Purposes, Perceptions, Practices. London, Routledge Falmer.

Pierce, L. V. (2002). Performance-Based Assessment: Promoting Achievement for Language Learners. Center for Applied Linguists (ERIC/CLL News Bulletin), 26(1), 1-3.

Richards, J. C., \& Renandya, W. A. (2002). Methodology in Language Teaching: An Anthology of Current Practice. Cambridge University Press. https://doi.org/10.1017/CBO9780511667190

Sarıçoban, A. (2011). A Study on the English Language Teachers’ Preparations of Tests. Hacettepe Universitesi Ĕgitim Fakültesi Dergisi, 41(41), 398-410.

Shapiro, E. S. (1987). Behavioral Assessment in School Psychology, by Lawrence Erlbaum Associates, New Jersey, London.

Stiggins, R. J. (2002). Assessment Crisis: The Absence of Assessment for Learning. Phi-Delta Kappan, 83(10), 758-765. https://doi.org/10.1177/003172170208301010

Taras, M. (2005). Assessment- Summative and Formative-Some Theoretical Reflections. British Journal of Educational Studies, 53(4), 466-478. https://doi.org/10.1111/j.1467-8527.2005.00307.x

Wang, K. H., Wang, T. H., Wang, W. L., \& Huang, S. C. (2006). Learning styles and formative assessment strategy: enhancing student achievement in Web-based learning. Journal of Computer Assisted Learning, 22(3), $207-217$. https://doi.org/10.1111/j.1365-2729.2006.00166.x

Watering, G., Gijbels, D., Dochy, F., \& Rijt, J. (2008). Students’ Assessment Preferences, Perceptions of Assessment and Their Relationships to Study Results. High Education, 56, 645-658. https://doi.org/10.1007/s10734-008-9116-6

Wojtczak, A. (2002). Medical Education Terminology. Medical Teacher, 24(4), $357-357$. https://doi.org/10.1080/01421590220145699

\section{Notes}

Note: A preliminary version of this article was presented orally at the GlobELT Conference held in Belgrade-Serbia on May 10-13, 2018.

\section{Copyrights}

Copyright for this article is retained by the author(s), with first publication rights granted to the journal.

This is an open-access article distributed under the terms and conditions of the Creative Commons Attribution license which permits unrestricted use, distribution, and reproduction in any medium, provided the original work is properly cited. 